\title{
Estimasi Emisi Gas Metana dari Fermentasi Enterik Ternak Ruminansia Menggunakan Metode Tier-1 di Indonesia
}

\section{Estimate of Methane Emissions from Enteric Fermentation by Ruminant Animals Using Tier-1 Methods in Indonesia}

\author{
SINDU AKHADIARTO DAN MUHAMAD N. ROFIQ \\ Pusat Teknologi Produksi Pertanian, Badan Pengkajian dan Penerapan Teknologi \\ Kawasan Puspiptek, Serpong, Tangerang Selatan 15314 \\ akhadiarto@yahoo.com
}

\begin{abstract}
Ruminant animals in animal husbandry, including cattle, goat, sheep and buffalo have a special digestive system that possible to emit methane outside to the atmosphere by their eructation. The aim of this research was to estimate methane $\left(\mathrm{CH}_{4}\right)$ emission or production from ruminant animal in Indonesia using Tier-1 Method (2007). Estimation of emission of $\mathrm{CH}_{4}$ from enteric fermentation showed a positive correlation among the ruminant population and the emission. Indonesia has ruminant animal population growth 5.55\%/year with 5.35\% $\mathrm{CH}_{4}$ emission from enteric fermentation. The total emission of $\mathrm{CH}_{4}$ was $1.066,63 \mathrm{Gg} \mathrm{CH}_{4}$ year or $22,40 \mathrm{Gg} \mathrm{CO}_{2}$ equivalent/year in 2013. It was lower than total emissions from livestock in the word. As a conclusion, estimation of $\mathrm{CH}_{4}$ emission from ruminant enteric fermentation in Indonesia should be developed by another method that was supported by certain data about sex and population age of ruminant and comprehensive of the digestion ruminant experiment.
\end{abstract}

Keywords: emission, methane, ruminant, enteric fermentation.

\begin{abstract}
ABSTRAK
Ternak ruminansia seperti sapi, kambing, domba dan kerbau mempunyai sistem pencernaan khusus yang memungkinkan melepas gas metana $\left(\mathrm{CH}_{4}\right)$ keluar ke atmosfer melalui proses eruktasi. Tujuan dari penelitian ini adalah menduga total emisi gas $\mathrm{CH}_{4}$ dari fermentai enterik ternak ruminansia di Indonesia melalui metode Tier-1 (2007). Hasil perhitungan estimasi emisi gas $\mathrm{CH}_{4}$ dari fermentasi enterik ternak ruminansia menunjukkan bahwa ada hubungan positif antara populasi dengan nilai estimasi emisinya. Indonesia mempunyai tingkat pertumbuhan ternak ruminansia sebesar $5.55 \%$ per tahun dengan nilai estimasi emisi gas $\mathrm{CH}_{4}$ dari fermentasi enterik sebesar 5.35\%. Nilai total estimasi emisi gas $\mathrm{CH}_{4}$ dari fermentasi enterik ternak ruminansia adalah sebesar $1.066,63 \mathrm{Gg} \mathrm{CH}_{4} /$ tahun atau $22,40 \mathrm{Gg} \mathrm{CO}$ ekuivalen/tahun pada tahun 2013. Nilai emisi tersebut sangat jauh lebih rendah jika dibandingkan dengan total emisi gas $\mathrm{CH}_{4}$ dari sektor peternakan di beberapa Negara di dunia. Kesimpulan dari hasil penelitian ini adalah estimasi emisi gas $\mathrm{CH}_{4}$ dari fermentasi enterik ternak ruminansia di Indonesia perlu dikembangkan melalui pendekatan metode estimasi lainnya (Tier-2 atau Tier-3) yang memerlukan dukungan data yang lengkap mengenai karakteristik ternak dan koefisien cerna energi ternak ruminansia dengan pakan yang berbeda di Indonesia.
\end{abstract}

Kata kunci : emisi, metana, ruminansia, fermentasi enterik

\section{PENDAhULUAN}

Pemanasan global (global warming) adalah suatu proses meningkatnya suhu rata-rata atmosfer, laut dan daratan bumi. Pemanasan global ini disebabkan oleh efek gas rumah kaca (green house effect), yaitu terjadinya peningkatan akumulasi gas rumah kaca, diantaranya berupa karbon dioksida $\left(\mathrm{CO}_{2}\right)$ dan beberapa jenis gas lainnya seperti metana. Peningkatan ini diakibatkan oleh aktivitas industri, sisa pembakaran bahan bakar minyak bumi dan juga sektor pertanian, yang termasuk didalamnya bidang peternakan, khususnya ternak ruminansia.
Sesuai dengan protokol Montreal, gas rumah kaca (GRK) yang terpenting dalam atmosfir adalah $\mathrm{CO}_{2}, \mathrm{CH}_{4}$ dan $\mathrm{N}_{2} \mathrm{O}$ disamping $\mathrm{CCF}, \mathrm{HFC}$, dan PFC. Lembaga internasional "Intergovernmental Panel on Climate Change (IPCC)" melalui climate change 2007 synthesis report menduga bahwa kontribusi sektor pertanian pada emisi GRK di atmosfir sebesar $13.5 \%^{(1)}$, tetapi emisi gas $\mathrm{CH}_{4}$ dan $\mathrm{N}_{2} \mathrm{O}$ bertambah secara global dalam kisaran $17 \%$ dari tahun 1990 sampai dengan tahun $2005^{(2)}$. Kontribusi global sektor peternakan terhadap GRK secara langsung sebesar 8,5 dan secara tidak langsung sebesar 16,5 Gt $\mathrm{CO}_{2}$ per tahun, 
yang dihitung berdasarkan estimasi global emisi GRK dari pertanian sebesar $17 \%$ sampai dengan $32 \%$ dari total emisi GRK dari aktivitas manusia (emisi antropogenik) ${ }^{(3)}$. Menurut laporan "Fourth assessment report (AR4)" dalam IPCC $2006^{(4)}$ dijelaskan bahwa gas metana $\left(\mathrm{CH}_{4}\right)$ memiliki potensi untuk pemanasan global (global warming potential/GWP) sebesar 25 kali emisi gas $\mathrm{CO}_{2}$ ekuivalen, sedangkan gas $\mathrm{N}_{2} \mathrm{O}$ memiliki gas GWP $298 \mathrm{CO}_{2}$ ekuivalen ${ }^{(4)}$.

Tujuan penelitian ini adalah untuk mendapatkan nilai estimasi emisi gas metana dari fermentasi enterik ternak ruminansia di Indonesia menggunakan metode Tier- $1^{(4)}$.

\subsection{Emisi GRK dari Sektor Pertanian.}

Emisi Gas Rumah Kaca (GRK) dari sektor pertanian utamanya terdiri dari gas $\mathrm{CH}_{4}$ dan $\mathrm{N}_{2} \mathrm{O}$ yang bersumber dari hewan dan eksretanya (manur), ladang pertanian (eksreta hewan ruminansia yang di gembalakan serta pupuk kimia) dan dari kandang yang menggunakan jerami atau litter sebagai alas kandang (bedding). Pada tahun 2005, estimasi fermentasi enterik hewan ruminansia yang menghasilkan gas $\mathrm{CH}_{4}$ sekitar $32 \%$ dari total emisi Non $\mathrm{CO}_{2}$ yang bersumber dari sektor pertanian ${ }^{(5)}$. Total emisi gas $\mathrm{CH}_{4}$ yang berasal dari sektor pertanian sebesar $60 \%$ dengan $40 \%$ berasal dari sektor peternakan. Gas metana $\mathrm{CH}_{4}$ dari sektor peternakan umumnya bersumber dari hewan ruminansia melalui fermentasi enterik sebesar 80 $-89.5 \%$ dan manur sebesar $10 \%^{(1)}$.

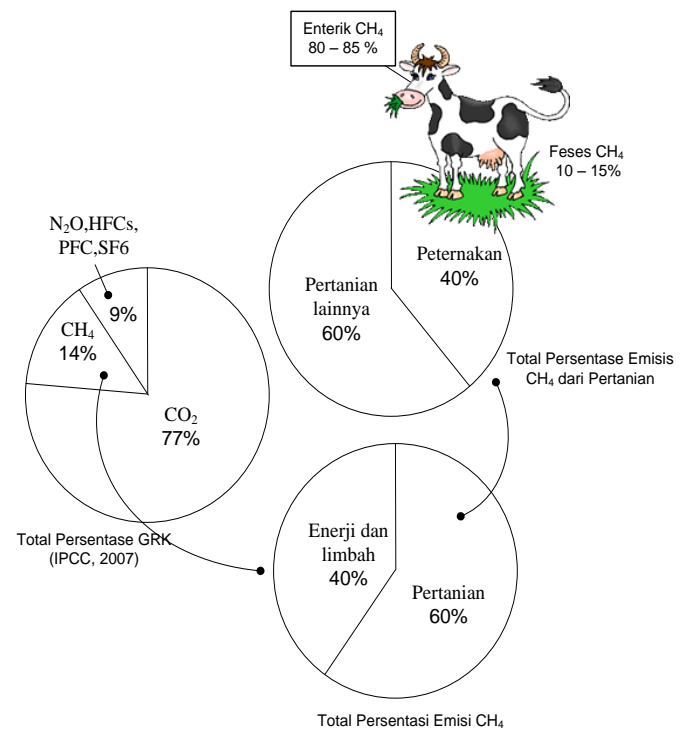

Gambar 1. Emisi gas Metana $\left(\mathrm{CH}_{4}\right)$ dari sektor pertanian dan peternakan (modifikasi dari IPCC, 2007).

Sektor peternakan secara rinci berkontribusi pada emisi GRK lebih besar pada emisi gas $\mathrm{CH}_{4}$ sebesar $44 \%$, kemudian gas $\mathrm{N}_{2} \mathrm{O} 29 \%$ dan gas
$\mathrm{CO}_{2} 27 \%{ }^{(1)}$. Fermentasi enterik dari ternak ruminansia merupakan sumber emisi kedua terbesar sekitar $40 \%$ dari total emisi GRK dari sektor peternakan.

\subsection{Emisi Gas Metana $\left(\mathrm{CH}_{4}\right)$ dari Fermentasi Enterik Ternak Ruminansia}

Emisi gas rumah kaca dari sektor peternakan yaitu emisi gas $\mathrm{CH}_{4}$ yang bersumber dari fermentasi enterik ternak ruminansia dan gas $\mathrm{N}_{2} \mathrm{O}$ yang bersumber dari manajemen manur (kotoran ternak). Emisi $\mathrm{CO}_{2}$ dari sektor peternakan tidak dapat di estimasi karena asumsi tahunan dari emisis $\mathrm{CO}_{2}$ dari sektor peternakan di anggap tidak ada (zero) karena fotosintesis tanaman $^{(4)}$.

Ternak ruminasia yang antara lain sapi, kerbau, domba, dan kambing memiliki sistem cerna yang khusus melalui empat macam kompartisi bagian perut (rumen, retikulum, omasum dan abomasum). Oleh karena itu sistem cerna pada ternak ruminansia terdiri atas kecernaan fisik, enzimatis, mikrob dan kimia. Semua tipe kecernaan tersebut banyak terjadi di dalam bagian perut besar ruminansia yaitu rumen yang mengandung beranekaragam mikroorganisme. Ekosistem rumen merupakan ekosistem anaerob sehingga oksidasi atau metabolisme bahan pakan seperti karbohidrat dan protein untuk menghasilkan energi dilakukan melalui dehidrogenasi ${ }^{(6)}$.

Konversi nutrisi bahan pakan menjadi gas metana $\left(\mathrm{CH}_{4}\right)$ dalam rumen melibatkan integrasi beberapa aktifitas spesies mikroorganisme yang berakhir pada aktifitas bakteri metanaogenesis. Mikroorganisme utama dalam rumen melakukan hidrolisis protein, karbohidrat, dan polimer dinding sel tanaman menjadi asam asam amino dan gula yang lebih sederhana. Produk tersebut akan difermentasi menjadi asam lemak mudah terbang (Volatile Fatty Acid = VFA), hidrogen $\left(\mathrm{H}_{2}\right)$ sebagai produk sekunder dari sistem cerna mikroorganisme dalam rumen. Komponen utama VFA yaitu asam asetat, propionat dan butirat yang terbentuk akan digunakan dan diserap oleh ternak ruminansia sebagai sumber energi untuk produktivitasnya. Produk sekunder lainnya yaitu dihidrogen $\mathrm{H}_{2}$ di hasilkan dari organisme melalui jalur fermentasi asam asetat ${ }^{(7)}$.

$\mathrm{C}_{6} \mathrm{H}_{12} \mathrm{O}_{6}+2 \mathrm{H}_{2} \mathrm{O} \rightarrow 2 \mathrm{C}_{2} \mathrm{H}_{4} \mathrm{O}_{2}$ (asetat) $+2 \mathrm{CO}_{2}+8 \mathrm{H}$

$\mathrm{C}_{6} \mathrm{H}_{12} \mathrm{O}_{6}+4 \mathrm{H} \rightarrow 2 \mathrm{C}_{3} \mathrm{H}_{6} \mathrm{O}_{2}$ (propionat) $+2 \mathrm{H}_{2} \mathrm{O}$

$\mathrm{C}_{6} \mathrm{H}_{12} \mathrm{O}_{6} \rightarrow \mathrm{C}_{4} \mathrm{H}_{8} \mathrm{O}_{2}$ (butirat) $+2 \mathrm{CO}_{2}+4 \mathrm{H}$

$\mathrm{CO}_{2}+8 \mathrm{H} \rightarrow \mathrm{CH}_{4}+2 \mathrm{H}_{2} \mathrm{O}$

Laju produksi gas $\mathrm{CH}_{4}$ dari fermentasi enterik pada ternak ruminansia sangat tergantung kepada jumlah konsumsi pakan serta jumlah energi yang dikonsumsinya(1). Tiga faktor utama dalam pembentukan gas $\mathrm{CH}_{4}$ dari fermentasi 
enterik ruminansia adalah : 1) Laju fermentasi bahan organik dari pakan yang dikonsumsinya; 2) Tipe VFA yang dihasilkan menunjukkan tingkat kelebihan sisa $\mathrm{H}_{2}$ yang dihasilkan untuk di rubah menjadi gas $\mathrm{CH}_{4}$ oleh bakteri metanaogenesis ${ }^{(8)}$. Oleh karena itu, emisi gas $\mathrm{CH}_{4}$ yang dihasilkan dari fermentasi ternak ruminansia juga berpengaruh terhadap hilangnya produktifitas sebagai energi yang hilang disamping pengaruhnya terhadap sumbangan emisi GRK dari sektor pertanian.

Dilaporkan oleh Hagemann, et al. ${ }^{(9)}$, bahwa kontribusi total ternak perah terhadap emisi GRK masih belum pasti terhitung secara tepat sehubungan dengan pendekatan metode estimasi emisi tersebut pada setiap level fisiologis hewan ruminansia. Estimasi lain yang dihasilkan dari beberapa analisis silang terhadap 117 tipe kandang dan peternakan dari 38 negara memeliki hasil estimasi rataan emisi GRK sebesar $1,50 \mathrm{~kg} \mathrm{CO}$ equivalents $\left(\mathrm{CO}_{2}\right.$-eq. $) / \mathrm{kg}$ susu yang dihasilkan.

\section{BAHAN DAN METODE}

Estimasi perhitungan emisi gas $\mathrm{CH}_{4}$ dari fermentasi enterik ternak ruminansia menggunakan data populasi dari statistik peternakan dan kesehatan hewan tahun $2013^{(10)}$. Data pertambahan populasi ternak ruminansia menggunakan konversi satuan unit ternak (ST).

Penggunaan faktor emisi didasarkan pada karakteristik ternak pada negara berkembang dengan data baku yang sudah ditetapkan oleh IPCC $^{(4)}$.

\subsection{Pemilihan Metode Estimasi Emisi Gas $\mathrm{CH}_{4}$ dari Fermentasi Enterik Ternak Ruminansia.}

Metode estimasi $\mathrm{CH}_{4}$ dari peternakan dilakukan menggunakan beberapa metode estimasi yang disarankan oleh IPCC, $2006^{(4)}$ mengenai guidelines for national greenhouse gas inventories. Metode tersebut membutuhkan definisi dan kategori/subkategori jenis ternak, data populasi, konsumsi pakan dan karakteristiknya mengunakan metode Tier yang berjenjang (Tier-1, Tier-2 dan Tier-3). Prosedur estimasinya mendefinisikan subkategori ternak, perkembangan data populasi dan karakteristik pakan.

Ternak ruminansia adalah ternak yang secara anatomi mempunyai empat macam perut yaitu rumen, retikulum, omasum dan abomasu sehingga dapat mengkonsumsi pakan berserat lebih efisien. Ternak ruminansia contohnya adalah sapi, kerbau, kambing, domba dan kancil. Emisi gas metana dari fermentasi enterik ternak ruminansia diperoleh dari hasil metabolisme pakan berserat yang menghasilkan gas Hidrogen bebas yang dapat berubah menjadi gas metana oleh mikroba yang ada dalam rumen. Oleh karena itu beberapa faktor yang mempengaruhi faktor emisi gas metana dari fermentasi enterik adalah populasi ternak ruminansia, jenis pakan yang dikonsumsi dan keseimbangan jenis mikroba yang ada di dalam rumen.

Langkah awal untuk melakukan kategori dan subkategori sebagai berikut :

- Identifikasi spesies ternak yang ada khususnya ruminansia

- Kaji ulang metode estimasi emisi untuk setiap kategori yang relevan untuk memilih metode yang tepat (Tier-1, Tier-2 atau Tier-3)

Tier-1 adalah metode estimasi emisi Gas $\mathrm{CH}_{4}$ dari fermentasi enterik ternak ruminansia dengan membagi kelompok populasi ternak kedalam subkelompok.

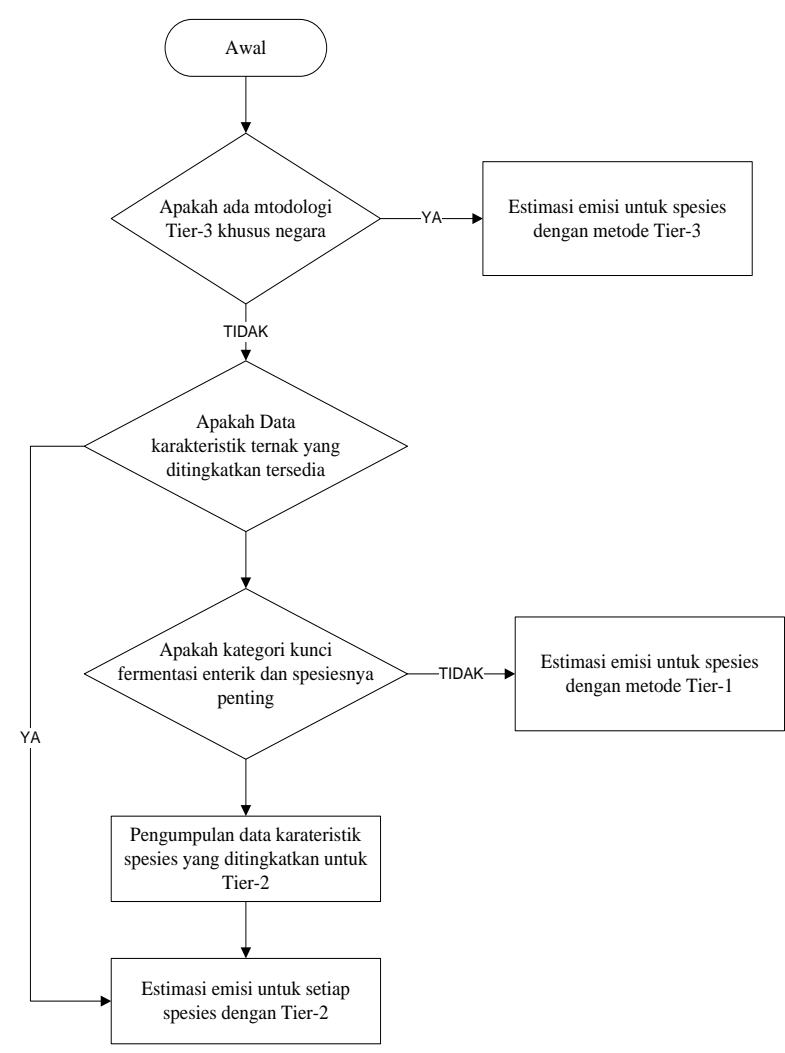

Gambar 2. Diagram pohon keputusan untuk memilih metode estimasi emisi gas $\mathrm{CH}_{4}$ dari fermentasi enterik ternak ruminansia ${ }^{(4)}$. Sumber: IPCC ${ }^{(4)}$.

Hasil analisis berdasarkan pohon keputusan untuk memilih metode estimasi emisi gas $\mathrm{CH}_{4}$ dari fermentasi enterik ternak ruminansia di Indonesia, maka metode Tier-1 merupakan metode yang dapat dilakukan pada kondisi Indonesia saat ini. Penggunaan metode Tier-2 dan Tier-3 memerlukan peningkatan pengkayaan 
data karakteristik ternak, konsumsi pakan dan energi.

\subsection{Metode Estimasi Tier-1 Emisi Gas $\mathrm{CH}_{4}$ dari fermentasi enterik ternak ruminansia.}

Metode estimasi Tier-1 untuk emisi gas $\mathrm{CH}_{4}$ dari fermentasi enterik ternak ruminansia dilakukan dengan beberapa tahapan yaitu :

- Perhitungan populasi ternak :

Estimasi perhitungan emisi gas $\mathrm{CH}_{4}$ dari fermentasi enterik ternak ruminansia menggunakan data populasi dari statistik peternakan dan kesehatan hewan tahun $2013^{(10)}$. Data pertambahan populasi ternak ruminansia menggunakan konversi satuan unit ternak (ST).

- Penggunaan faktor emisi :

Penggunaan faktor emisi didasarkan pada karakteristik ternak pada negara berkembang dengan data baku yang sudah ditetapkan oleh IPCC $^{(4)}$ pada Annex 10A.1 Guidelines for national greenhouse gas inventories (Tabel 1).

Tabel 1. Faktor emisi $\mathrm{CH}_{4}$ dari sistem cerna dan kotoran ternak.

\begin{tabular}{lcc}
\hline $\begin{array}{c}\text { Jenis } \\
\text { Ternak }\end{array}$ & $\begin{array}{c}\text { Faktor emisi } \\
\text { pencernaan } \\
\mathrm{Kg} \mathrm{CH}_{4} / \mathrm{ek} / \mathrm{thn}\end{array}$ & $\begin{array}{c}\text { Faktor emisi } \\
\text { kotoran ternak } \\
\mathrm{Kg} \mathrm{CH}_{4} / \mathrm{ek} / \mathrm{thn}\end{array}$ \\
\hline Sapi Potong & 47 & 1,00 \\
Sapi Perah & 61 & 31,00 \\
Domba & 5 & 0,15 \\
Kambing & 5 & 0,70 \\
Kerbau & 55 & 2,00 \\
Kuda & 18 & 1,64 \\
Unggas & 0 & 0.03 \\
Babi & 1 & 7,00 \\
\hline
\end{tabular}

Sumber: IPCC (2006). Guidelines for National Greenhouse Gas Inventories ${ }^{(4)}$.

Faktor emisi pencernaan dari ternak ruminansia adalah faktor emisi $\mathrm{CH}_{4}$ yang di hasilkan dari fermentasi enterik ternak ruminansia. Perhitungan total emisi gas $\mathrm{CH}_{4}$ per kategori ternak ruminansia.

Total emisi dilakukan melalui perhitungan menggunakan formulasi di bawah ini :

Emission $=\mathrm{EF}_{(\mathrm{T})} \times\left[\mathrm{N}_{(\mathrm{T})} / 10^{6}\right]$

Emission = emisi $\mathrm{CH}_{4}$ dari fermentasi enterik, ( $\mathrm{Gg} \mathrm{CH}_{4} /$ tahun)

$\mathrm{EF}_{(\mathrm{T})} \quad=$ faktor emisi kategori ternak (tabel 1)

$\mathrm{T}=$ jenis ternak ruminansia

Total $\mathrm{CH}_{4 \text { Eneterik }}=\Sigma_{\mathrm{i}} \mathrm{Ei}$

$E_{i}=$ emisi untuk setiap jenis ternak

\section{HASIL DAN PEMBAHASAN}

\subsection{Estimasi Emisi Gas $\mathrm{CH}_{4}$ dari Sektor Peternakan di Indonesia}

Hasil perhitungan estimasi emisi gas $\mathrm{CH}_{4}$ menggunakan pendekatan metode Tier- $1^{(4)}$, menunjukkan bahwa emisi gas $\mathrm{CH}_{4}$ dari fermentasi enterik ternak ruminansia di Indonesia mempunyai kontribusi yang besar dari ternak sapi potong $780,53 \mathrm{Gg} / \mathrm{thn}$ atau sebesar $73,18 \%$ dari seluruh total kontribusi emisi $\mathrm{CH}_{4}$ enterik dari ternak ruminansia di Indonesia pada tahun 2013 (Tabel 3 dan Gambar 3).

Tabel 2. Populasi ternak ruminansia di Indonesia pada tahun $2013^{(10)}$.

\begin{tabular}{lrr}
\hline \multirow{2}{*}{ Jenis ternak } & \multicolumn{2}{c}{ Populasi Ruminansia } \\
\cline { 2 - 3 } & ribu ekor & \multicolumn{1}{c}{ ribu ST } \\
\hline sapi Potong & $16,607.00$ & $16,607.00$ \\
Sapi Perah & 636.00 & 890.40 \\
Kerbau & $1,484.00$ & $1,484.00$ \\
Kambing & $18,576.00$ & $1,857.60$ \\
Domba & $14,560.00$ & $1,456.00$ \\
\hline TOTAL & $51,863.00$ & $22,295.00$ \\
\hline Keterangan:ST & Sanan Ternak &
\end{tabular}

Keterangan : ST $=$ Satuan Ternak.

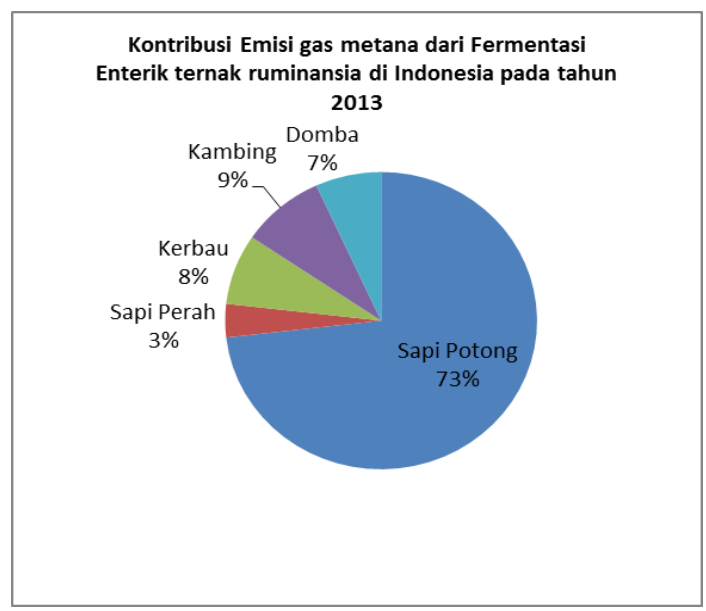

Gambar 3. Kontribusi jenis ternak ruminansia terhadap emisi gas $\mathrm{CH}_{4}$ fermentasi enterik di Indonesia tahun 2013 metode Tier-1

Hal ini sejalan dengan peningkatan populasi ternak sapi potong di Indonesia dalam rangka percepatan swasembada daging nasional (Tabel 2). Sementara kontribusi terkecil dari jenis ternak sapi perah $38,80 \mathrm{Gg} / \mathrm{thn}$ atau $3,64 \%$ dari total kontribusi emisi gas $\mathrm{CH}_{4}$ ternak ruminansia di Indonesia (Tabel 3 dan Gambar 3). Hal ini berhubungan dengan populasinya yang rendah dan tidak menyebar pada suluruh wilayah 
Indonesia karena kondisi lingkungan dan geografi.

Jumlah total emisi gas $\mathrm{CH}_{4}$ dari fermentasi enterik ternak ruminansia sebesar 1,07 $\mathrm{Gg}$ $\mathrm{CH}_{4} /$ tahun atau sebesar $22.40 \mathrm{Gg} \mathrm{CO}$-eq/th. Nilai konversi emisi menjadi $\mathrm{CO}_{2}$ ekuivalen $\left(\mathrm{CO}_{2}-\right.$ eq) menunjukkan bahwa satuan emisi gas rumah kaca di standarkan dalam satuan $\mathrm{CO}_{2}$ dengan nilai global warming potential yang berbeda diantara gas rumah kaca. Nilai GWP emisi gas $\mathrm{CH}_{4}$ adalah sebesar 21 kali emisi dari emisi $\mathrm{CO}_{2}$. Total nilai emisi gas $\mathrm{CH}_{4}$ dari fermentasi enterik ternak ruminansia di Indonesia pada tahun 2013 tersebut sangat jauh lebih kecil jika di bandingkan dengan nilai emisi gas $\mathrm{CH}_{4}$ dari sektor peternakan dunia yaitu sebesar $0,72 \%$ dari total emisi $\mathrm{CH}_{4}$ dari sektor peternakan dunia pada tahun 2005 (3.1 Gt $\mathrm{CO}_{2}$-eq/tahun).

Tabel 3. Emisi Gas $\mathrm{CH}_{4}$ dari Fermentasi Enterik Ternak Ruminansia di Indonesia tahun 2013

\begin{tabular}{lrrr}
\hline \multirow{2}{*}{$\begin{array}{c}\text { Jenis } \\
\text { Ternak }\end{array}$} & \multicolumn{3}{c}{ Emisi Gas $\mathrm{CH}_{4}$ Fermentasi Enterik } \\
\cline { 2 - 4 } $\mathrm{CH}_{4} /$ thn & \multicolumn{1}{c}{$\begin{array}{c}\text { Gg CO} 2^{-} \\
\text {eq/thn }\end{array}$} & $\begin{array}{c}\% \\
\text { Kontribusi }\end{array}$ \\
\hline Sapi Potong & 780,53 & $16.391,11$ & 73,18 \\
Sapi Perah & 38,80 & 814,72 & 3,64 \\
Kerbau & 81,62 & $1.714,02$ & 7,65 \\
Kambing & 92,88 & $1.950,48$ & 8,71 \\
Domba & 72,80 & $1.528,80$ & 6,83 \\
\hline \multicolumn{1}{c}{ TOTAL } & $1.066,63$ & $22.399,13$ & 100,00 \\
\hline
\end{tabular}

Perkembangan populasi yang secara linear meningkatkan produksi gas $\mathrm{CH}_{4}$ dari ternak ruminansia sudah seharusnya mulai dilakukan mitigasi untuk pengurangan emisi tersebut. Pertambahan populasi ternak ruminansia (satuan ternak) selama lima tahun (2009 sampai dengan 2013) sebesar 5.55\%/tahun menyebabkan pertambahan emisi gas $\mathrm{CH}_{4}$ dari fermentasi enterik ternak ruminansia sebesar $5.35 \%$ /tahun (Gambar 4).

Usaha mitigasi yang dilakukan menggunakan prinsip efisiensi penggunaan energi pakan untuk di konversi menjadi produk ternak (daging dan susu). Sehingga tetap memenuhi faktor ekonomi usaha dalam budidaya ternak ruminansia yang berwawasan lingkungan. Mitigasi atau pengurangan emisi gas $\mathrm{CH}_{4}$ dari kotoran ternak ruminansia dapat dilakukan dengan mudah dengan memanfaatkanya sebagai biogas. Tetapi mitigasi emisi gas $\mathrm{CH}_{4}$ dari fermentasi enterik ternak ruminansia sulit dilakukan karena terlepas melalui pernafasan ternak saat melakukan eruktasi (bersendawa).

Secara langsung emisi gas $\mathrm{CH}_{4}$ dari fermentasi enterik ternak ruminansia dipengaruhi oleh konsumsi pakan terutama konsumsi bahan kering pakan dengan kandungan serat kasar yang tinggi. Hal ini sesuai dengan hasil penelitian
Ramin dan Huhtanen ${ }^{(11)}$, bahwa konsumsi pakan adalah penentu utama dari total produksi $\mathrm{CH}_{4}$.

Berdasarkan jumlah populasi ternak ruminansia di Indonesia ${ }^{(10)}$, maka total emisi gas $\mathrm{CH}_{4}$ dari fermentasi enterik ternak ruminansia mempunyai nilai yang besar di Propinsi Jawa Timur, Jawa Barat, Jawa Tengah, Sulawesi Selatan, NTB dan NTT $\left(>1000 \quad \mathrm{Gg} \quad \mathrm{CO}_{2}\right.$ ekuivalen/tahun). Sedangkan estimasi emisi gas $\mathrm{CH}_{4}$ terkecil pada Propinsi DKI Jakarta sebesar $5,74 \mathrm{Gg} \mathrm{CO}$ ekuivalen/tahun dengan populasi ternak ruminansia.

Perbedaan populasi yang menyebabkan perbedaan emisi gas metana dari fermentasi enterik ternak ruminansia di sebabkan oleh perbedaan komposisi bahan baku pakan dan kandungan nutrisinya yang dikoreksi nilai emisinya jika menggunakan metode Tier yang berbeda. Nilai tersebut di koreksi menjadi lebih rendah karena pengaruh nilai konsumsi energi pada tier-2 dan pengaruh nilai hasil metabolisme fermentasi enterik (VFA, pH, n-NH3) pada Tier$3^{(12)}$. Oleh karena itu hasil perhitungan emisi gas metana dari fermentasi enterik ternak ruminansia menggunakan Tier-1 juga menjadi bagian dari proses perhitungan emisi gas metana menggunakan metode Tier-2 dan Tier-3.

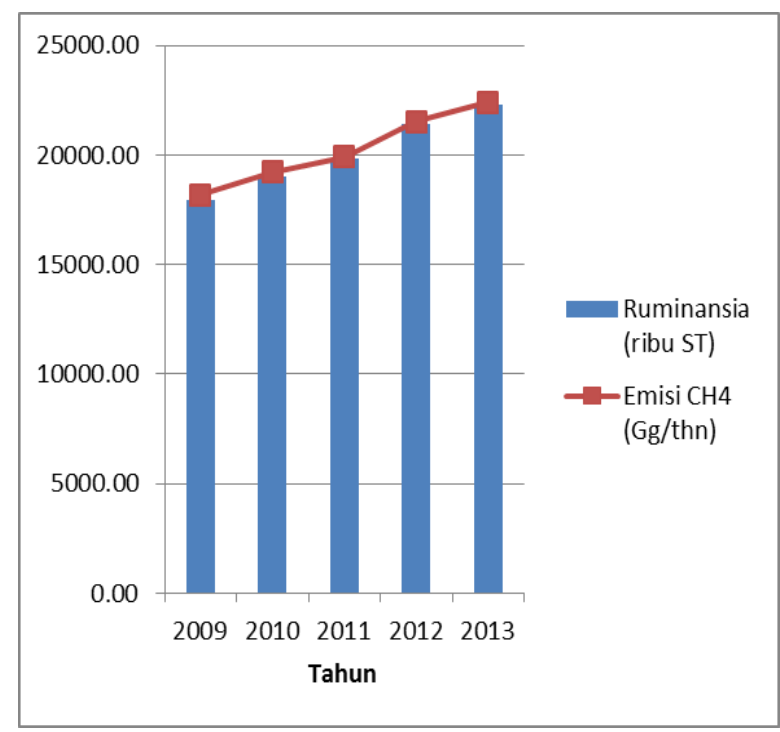

Gambar 4. Grafik hasil perhitungan emisi gas $\mathrm{CH}_{4}$ dari fermentasi enterik ternak ruminansia berdasarkan pertambahan populasi ruminansia selama 5 tahun (Gg/thn).

\subsection{Peluang dan Strategi Mitigasi Gas $\mathrm{CH}_{4}$ dari Sektor Peternakan di Indonesia}

Sejak diketahuinya hubungan yang erat antara efisiensi konversi pakan dengan produksi rumen gas metana ${ }^{(13)}$, maka dilakukan beberapa penelitian untuk mengurangi atau mitigasi emisi gas $\mathrm{CH}_{4}$ dari produksi fermentasi enterik ternak 
ruminansia melalui manipulasi pakan untuk meningkatkan efisiensi konversi tersebut. Usaha mitigasi lainya juga sudah dikembangkan melalui beberapa strategi mitigasi yang dihasikan dari beberapa hasil penelitian terhadap ternak ruminansia secara in vitro ataupun in vivo.

Beberapa strategi mitigasi tersebut terangkum dalam diagram Gambar $5^{(14)}$. Strategi mitigasi yang banyak dilakukan saat ini melalui beberapa hasil penelitian untuk meningkatkan efisiensi penggunaan nutrisi dan energi pakan serta modifikasi rumen untuk mengurangi pemanfaatan gas $\mathrm{H}_{2}$ menjadi $\mathrm{CH}_{4}$ dalam rumen.

Strategi mitigasi masa depan terhadap pengurangan emisi gas $\mathrm{CH}_{4}$ dari fermentasi enterik di kembangkan pada level penelitian ternak ruminansia sebagai obyek melalui rekayasa genetik, seleksi ternak. Selain itu juga penelitian pada level mikroorganisme rumen melalui teknik biomolekuler serta penelitian pada level tanaman sebagai sumber pakan ternak. Sedangkan penelitian pada level nutrisi atau manipulasi pakan dianggap sebagai strategi mitigasi yang sangat efisien. Strategi lainnya yang lebih efektif adalah penggunaan beberapa pakan tambahan yang dapat memanipulasi fermentasi enterik dari ternak ruminansia seperti minyak minyak esensial yang tersedia sangat banyak di Indonesia. Penggunaan minyak esensial dari cengkeh dan kulit jeruk manis di laporkan dapat mengurangi emisi gas metana in vitro dari fermentasi enterik sebesar 12,31 ml/BK dan $14,90 \mathrm{ml} / \mathrm{BK}$ pakan yang dikonsumsinya ${ }^{(15)}$.

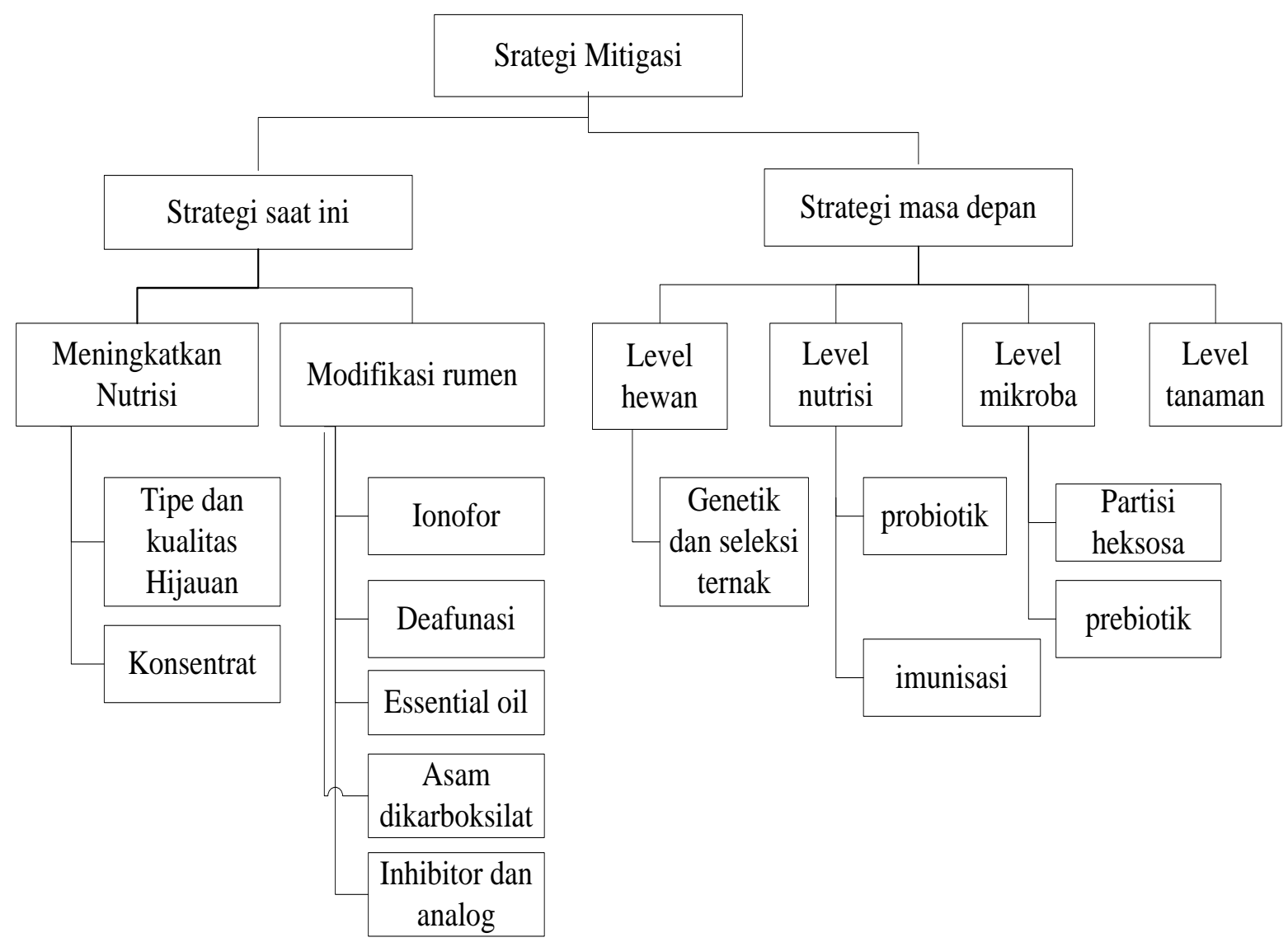

Gambar 5. Strategi mitigasi gas $\mathrm{CH}_{4}$ dari fermentasi enterik ternak ruminansia ${ }^{(13)}$

Strategi mitigasi gas $\mathrm{CH}_{4}$ dari fermentasi enterik ternak pada strategi manipulasi mikroba rumen telah di identifikasi yang meliputi intervensi untuk mengurangi gas $\mathrm{H}_{2}$ yang dihasilkan dari metabolisme nutrisi pakan, pengembangan alternatif penggunaan kelebihan gas $\mathrm{H}_{2}$, pemberian anti metanaogen serta penghilangan atau pengurangan protozoa dalam rumen $^{(16)}$.

Strategi modifikasi rumen dilakukan melalui suplementasi minyak esensial dari tanaman dan senyawa aktif sekunder tanaman yang sudah dikaji oleh beberapa peneliti ${ }^{(17,18)}$. Kombinasi antara manajemen pakan dan peternakan merupakan opsi strategi terbaik yang dapat diimplementasikan untuk mengurangi emisi gas $\mathrm{CH}_{4}$ dari fermentasi enterik ternak ruminansia tanpa mengurangi produktivitasnya ${ }^{(19)}$. 


\section{KESIMPULAN}

Berdasarkan hasil kalkulasi estimasi produksi gas $\mathrm{CH}_{4}$ melalui metode Tier-1 (IPCC, 2006), kontribusi gas $\mathrm{CH}_{4}$ dari sektor peternakan di Indonesia masih sangat kecil tetapi perlu dilakukan metode estimasi melalui metode yang lebih akurat dari beberapa hasil penelitian di Indonesia.

Dasar teori metode Tier-1 menggunakan faktor emisi $\mathrm{CH}_{4}$ hasil penelitian yang dilakukan di luar kondisi fisiologis ternak dan jenis pakan yang dikonsumi oleh ternak di Indonesia. Oleh karena itu diperlukan penelitian untuk mendapatkan faktor emisi $\mathrm{CH}_{4}$ yang menggunakan ternak lokal yang ada di Indonesia dengan jenis pakan yang umum di konsumsi di Indonesia.

Manajamen budidaya dan manipulasi pakan dapat dilakukan sebagai strategi mitigasi $\mathrm{CH}_{4}$ dari fermentasi enterik ternak ruminansia di Indonesia sebagai strategi yang paling tepat berdasarkan kondisi sistem budidaya peternakan yang ada di Indonesia.

\section{PERSANTUNAN}

Makalah ini merupakan bagian dari kegiatan penelitian yang dibiayai oleh DIPA BPPT tahun 2015 WBS1 Perekayasaan Teknologi Produksi Peternakan, di Pusat Teknologi Produksi Pertanian (PTPP), Kedeputian Bidang Agroindustri dan Bioteknologi (TAB), BPPT. Hasil kajian ini merupakan bagian dari Keterpaduan antara ternak sapi dengan sawit pada Kegiatan Tekno Park di Pelalawan, Riau. Terima kasih disampaikan kepada Deputi Bidang TAB dan Direktur PTPP yang telah mengarahkan kegiatan penelitian ini dan mengizinkan makalah ini untuk diterbitkan dalam Jurnal.

\section{DAFTAR PUSTAKA}

1. IPCC. (2007). Climate Change 2007: Syntesis Report. A report of the intergovernmental panel on climate change. UNEP and WMO.

2. Smith, P., O. Andre'n, T. Karlsson, P. Pera"la", K. Regina,M. Rounsevell, B. van Wesemael, (2005). Carbon sequestration potential in European croplands has been overestimated. Global Change Biol. 11, 2153-2163.

3. Bellabary J, B. Foereid, A. Hastings, P. Smith, (2008). Cool Farming. Climate impacts of agriculture and mitigation potential. Greenpeace International, Amsterdam.

4. IPCC. (2006). Guidelines for National Greenhouse Gas Inventories. http ://www.ipccnggip.iges.or.jp/public/2006gl/ind ex.html.

5. Smith, P., O. Andre'n, T. Karlsson, P. Pera"la“, K. Regina,M. Rounsevell, B. van Wesemael, (2005). Carbon sequestration potential in European croplands has been overestimated. Global Change Biol. 11, 2153-2163

6. Martin, C., J. Rouel, J. P. Jouany, M. Doreau and Y. Chilliard. (2008). Methane output and diet digestibility in response to feeding dairy cows crude linseed, extruded linseed, or linseed oil. J Anim. Sci. 2008, 86:2642-2650.

7. Hegarty, R. S. (1999). Mechanism for competitively reducing rumnal methanogenesis. Aus.J. of Agric.Res. 50: 1299-1305.

8. Monteny, G., A. Bannink, D. Chadwick. (2006). Greenhouse gas abatement strategies for animal husbandry. Agric. Eco. And ev. 112 (2-3):163-70.

9. Hagemann, M., A. Ndambi, T. Hemme, U. Latacz-Lohmann. (2012). Contribution of milk production to global greenhouse gas emissions : An estimation sbased on typical farms. Environ Sci Pollut Res. 2012. 19:390402.

10. Ditjen Peternakan dan Kesehatan Hewan, (2014). Statistik Peternakan dan Kesehatan Hewan 2013. Kementerian Pertanian, Jakarta.

11. Ramin, M. and P. Huhtanen. (2013). Development of equation for predictiong methane emission from ruminants. J. Dairy Sci. $96: 1-18$.

12. Zhou, J.B., M.M. Jiang, and G.Q. Chen, (2007). Estimation of methane and nitrous oxide emission from livestock and poultry in China during 1949-2003. Energy Policy, 35(7):3759-3767.

13. Waghorn, G.C. and R.S. Hegarty. (2011). Lowering ruminan methane emissions through improved feed conversion efficiency.

14. Iqbal M.F., Y. Cheng, W. Zhu, and B. Zeshan. (2008). Mitigation of ruminant methane production : current strategies, constraints and future options. World J. Microbiol. Biotechnol. 24:2747-2755.

15. Rofiq, M.N., M. Gorgulu, O. Guney, and M. Boga (2012). Combination effects of clove and orange peel oils on rumen gas and methane production using in vitro gas production technique. Emissionsof Gasand Dust from Livestock, p.213 
16. Joblin K.N. (1996). Options for reducing methane emissions from ruminants in New Zealand and Australia. In: Bouma WJ, Pearman Gl, Manning MR eds.). Greenhouse: Coping with climate change, CSIRO Publishing, Collingwood, Australia, pp. 437-449.

17. Calsamiglia, S., M. Busquet, P. W. Cardozo, L. Castillejos, and Ferret. (2007). Essentials Oils for modifying rumen fermentation : A review, J. Dairy Sci. 90:2580-2595.
18. Rofiq, M. N., M. Gorgulu. (2014). Combination Effect of Clove and OrangePeel Oils on In Vitro and In Vivo RumenMethane Production in Goat. The 16th Asian Autsralian Animal Production Congress(AAAP) 10-14 Nov 2014. p. 13311334. ISBN: 978-602-8475-87-7.

19. Grainger C. dan K.A. Beauchemin. (2011). Can enteric methane emissions from ruminants be lowered without lowering their production?. Animal Feed Science and Technology 166-167:308-320. 